\title{
OBRAZ, INFORMACE, ENTROPIE
}

\author{
IMAGE, INFORMATION, ENTROPY: \\ IMAGE ANALYSIS USING RÉNYI ENTROPY \\ Dita Malečková, Renata Štysová Rychtáriková, Jan Urban \\ Univerzita Karlova; Jihočeská univerzita
}

\begin{abstract}
Abstrakt
Účel - Text je výzkumnou studií z oblasti analýzy obrazu využívající funkci informační entropie, a představuje alternativu k netransparentní práci s obrazy využívající neuronové sítě, která je v současnosti dominantní. Zároveň odkazuje na významný moment prolínání vědy a umění v oblasti abstraktního umění počátku 20. století.

Design/metodologie/přistup - Popisuje výzkum, v němž bylo dílo Františka Kupky použito jako vstupní obrazová informace v experimentu zahrnujícím originální metodu obrazové analýzy využívající funkci informační entropie (Rényiho entropie).

Výsledky - Hlavním př́nosem textu je design experimentu, který zahrnoval nejen výpočet informační entropie obrazu, ale i lidské trrídění obrazového materiálu a porovnání pomocí regresní analýzy a byl navržen jako pilotní průzkum zaměřený na vztah lidského vnímání, strojového vidění a přirozené i simulované komplexity.

Originalita/hodnota - Text poukazuje na současný stav v oblasti strojového vidění, jeho zvyšující se neprůhlednost (zejména v prrípadě použivání neuronových síti) a potřebu ho lépe teoreticky i prakticky uchopit pomocí jiných přístupů, např. pomocí navrženého matematického modelování.
\end{abstract}

Klíčová slova: informační věda, analýza obrazu, informační entropie, kulturní analytika, abstrakce, abstraktní umění, komplexita

\begin{abstract}
Purpose - The text is a research study in the field of image analysis using the information entropy function and represents an alternative to the non-transparent work with images using neural networks, which is currently dominant. At the same time, it refers to an important moment of the intersection of science and art in the field of abstract art of the early $20^{\text {th }}$ century.

Design/Methodology/Approach - It describes a research in which the work of František Kupka was used as input image information in an experiment involving an original method of image analysis using the function of information entropy (Rényi entropy).

Results - The design of the experiment included not only the computation of a function of image information entropy, but also human perception and their mutual comparison by regression analysis, and was designed as a pilot survey focused on the relationship between natural and simulated complexity.

Originality/Value - At the same time, it points to the current state of the field of machine vision, its increasing opacity, and the need to better grasp it theoretically and practically.
\end{abstract}

Keywords: information theory, image analysis, informational entropy, cultural analytics, abstraction, abstract art, complexity 
Analýza obrazu je bouřlivě se rozvíjejícím oborem, v němž v současnosti dominuje využití neuronových sítí (v současnosti jsou nejvýraznější metody tzv. hlubokého učení neboli deep learningu). Rychlý vývoj metod obrazové analýzy byl umožněn evolucí výpočetní technologie a samozřejmě i digitalizací informace a jejím následným zpracováním ve strojovém prostředí. Zkoumání obrazu a obrazové informace není jen čistě technickým oborem - prrispívají k němu také digitální humanitní vědy („digital humanities“), které propojují technické prrístupy, výpočetní metody, práci se soubory dat a interpretaci uvádějící objekt zkoumání do kontextu psychologie, filosofie, sémiologie a estetiky. Na významu získává oblast studia vizuální kultury jako společenského znakového systému.

Umělá inteligence je na poli analýzy obrazu využívána především v oblasti rozpoznávání tvarů - jednou z nejvýraznějších aplikací je rozpoznávání tváří, které je hojně využíváno pro různé typy kontroly lidské mobility. Jde v podstatě o vnímání smysluplných pravidelností ve složitém prostředí a aplikaci schopnosti detekování pravidelností či vzorů do strojového prostředí. Vyvijí se od sedmdesátých let 20. století, i když pionýrské práce $\mathrm{v}$ tomto oboru jsou již z padesátých let. Společnosti jako je Google v současnosti využívají bezprecedentního množství dat, která mají $\mathrm{k}$ dispozici. Právě Google a jeho projekt DeepLearning, jehož součástí je i populární DeepDream, představuje milník v práci s obrazovými daty. Metody strojového učení jsou rozvijeny pomocí konvolučních a adverzariálních neuronových sítí, které se skládají z vrstev malých výpočetních jednotek, které zpracovávají vizuální informaci hierarchicky. Každá vrstva jednotek může být chápána jako soubor obrazových filtrů, z nichž každý extrahuje určitý rys obrazu. Výstupem každé úrovně jsou pak tzv. př́íznakové mapy - různě filtrované verze vstupního obrazu, které vytvoři celkový příznakový prostor. Konvoluční neuronové sítě nevyužívá jen Google (TensorFlow, na němž je založen DeepDream), Amazon (Rekognition) či Facebook, v jejich prŕpadě je však klíčový rozdíl dán objemy dat, které mají k dispozici od svých uživatelů a které dále zpracovávají. Adverzariální sítě využívající interakce dvou neuronových sítí, jsou díky efektivitě, s níž zpracovávají a generují obrazy, využivány mimo jiné i v oblasti umělecké tvorby, za všechny jmenujme práci Maria Klingemana či Memo Aktena. Mimochodem první umělecké dílo vytvořené pomocí GAN (Generative Adversarial Network) bylo loni, tedy v roce 2018, vydraženo aukční síní Christie‘s za 432500 USD. (A okamžitě se rozvinula bouřlivá debata ohledně autorství, především proto, že dílo bylo vytvořeno na základě open software, tedy kódu, který dal jeho autor k dispozici na internetové síti.)

Problémem deep learningu neboli "hlubokého učenî" je jeho neprůhlednost a vyloučení instance lidského pozorovatele z celého procesu. Filozof Daniel Dennett mluví v této souvislosti o "competence without comprehension”, tedy kompetenci bez porozumění: Lidé se spoléhají na složitý algoritmus a na to, že je efektivnější než lidské vidění, stávají se pasivními diváky, kteří přihlížejí a přijímají výsledky doručené umělými neuronovými sítěmi bez možnosti kontroly. Automatizace vidění či strojové vidění ("machine vision”) je v současnosti jedním z nejaktuálnějších témat, kterým se po teoretické stránce zabývají autoři jako je Lev Manovich, Jonathan Crary a další. Teorie je ovšem v závěsu za praxí, která se díky iterativnímu akcelerujícímu technologickému postupu rozvijí bouřlivým tempem. 
"Boom“ používání neuronových sítí začal v roce 2009 především díky technologickému rozvoji hardwaru (největši roli hrály firmy jako Nvidia). Přibližně v roce 2014 dosáhly výzkumníci pomocí neuronových sítí úspěšnost na poli rozpoznání obrazu srovnatelnou s lidskou (viz např́klad statistiky z The Wolfram Language Image Identification Project), raketový start „deep learningu“ neboli hlubokého učení začal přibližně v roce 2012 a od té doby zaznamenává strojové učení a neuronové sítě nesporné úspěchy na poli rozpoznání, extrakce a aplikace obrazové informace v mnoha oblastech, včetně rozpoznání a přenosu uměleckého stylu. V záŕí 2015 uveřejnila skupina výzkumníků text nazvaný A Neural Algorithm of Artistic Style (Gatys \& Ecker \& Bethge, 2015), v němž ukázali, jak napodobit umělecký styl úpravou fotografie $\mathrm{s}$ využitím neuronové sítě. $\mathrm{K}$ získání informace o stylu bylo využito př́íznakového prostoru určeného původně $\mathrm{k}$ získávání informace o textuře. Toto využití neuronových sítí znamenalo milník ve vývoji. $\mathrm{V}$ předcházejícím období byla vizuální analýza uměleckých děl založená na zpracování informace o bodu čili pixelu (barva, jas, specifické hrany a kontury, podobnosti mezi tvary atd.). Mezi další tradiční postupy patřila perspektivní analýza, analýza světelných podmínek obrazu, kompozice, či tahů štětce. Neuronové sítě, které zpracovávají nepoměrně větší objemy dat, využívají pokročilé statistické metody a hlavně se učí, (v současnosti typicky od lidského supervizora, jde však zřejmě o přechodné období vedoucí $\mathrm{k}$ plné autonomii umělého vidění $\mathrm{k}$ rychlosti výpočetních procesů, které jsou mimo oblast lidského vnímání; viz např. text Abrupt rise of new machine ecology beyond human response time, $v$ němž autoři na příkladu systému burzy dokládají, že kolem roku 2008 začala vznikat nová strojová ekologie, tedy prostředí, $\mathrm{v}$ němž člověk ztrácí schopnost zasahovat $\mathrm{v}$ reálném čase), tedy pomocí zpětné vazby vylepšují své postupy nevídaným tempem, tak představují globální změnu př́stupu k obrazové analýze.

Zajímavým př́spěvkem $\mathrm{k}$ tématu vizuální analýzy uměleckých děl je práce českého matematika Jaroslava Nešetřila. V roce 2007 vyšel v publikaci Mathematics and Culture V článek Towards Matematical Aesthetics (Bálek \& Nešetřil, 2004), v němž je navržena metoda čtení obrazu pomocí pojmu grupy. Zjednodušeně řečeno jde o to, že obraz vnímáme na rozdíl od textu najednou v celku, nicméně při dalším „čtení “ ho intuitivně dělíme na menší části, které by mohly korespondovat s co-grupami. Profesor Nešetřil se svými spolupracovníky se ve výzkumu prezentovaném v článku namísto mikroanalýzy prvků obrazu zaměřil na makroanalýzu: sám ji označuje za snahu o topologii estetiky. Pro potřeby strojově zpracovatelné analýzy, která by zároveň postihovala lidský smysl pro krásu, se rozhodl použít jako invariant kombinatorickou entropii (“hereditary combinatorial entropy”) celku obrazu a jeho částí. Hlavní teze článku zní, že obrázek působí harmonicky, jestliže některé z jeho podobně významných částí mají stejné hodnoty kombinatorické entropie, a do značné míry se potvrdila.

V dizertační práci, kterou jedna ze spoluautorek obhájila v roce 2017 na Ústavu informačních studií a knihovnictví FF UK (Malečková, 2017), prezentovala projekt představující novou metodu analýzy obrazu, na němž spolupracovala s výzkumníky z Ústavu komplexních systémů Jihočeské univerzity. Bylo při ní využito výpočtů operujících s informační entropií v programu na rozpoznání vzorů, který v roce 2016 v Ústavu komplexních systémů vyvinuli pro účely analýzy buněčných tkání a který je založen na unikátním př́stupu výpočtu informačního př́nosu bodů neboli součtu hodnot entropií pixelů obrázku. 
Výsledkem představené metody je regresní model porovnávající strojovou informaci s lidskou percepcí. Získání matematického modelu tedy není podmíněno využitím umělé neuronové sítě.

My jsme tuto metodu aplikovali na analýzu uměleckých děl, konkrétně souboru kreseb pionýra abstraktního umění Františka Kupky. Mezi teoretické předpoklady jsme zahrnuli tezi o optimální míře (vizuálnî) informace, která je společná jak lidskému, tak umělému senzorickému systému. Ověření této hypotézy jsme provedli porovnáním lidského a strojového "vnímánî". Obrazovým vzorkem byl soubor Kupkových studií k cyklu Čtyři příběhy černé a bílé (Obr. 1), který vyšel v knižní podobě v roce 1926 a který nám v dostatečném rozlišení poskytlo Muzeum Kampa. Odkaz na zdrojová data výzkumu je uveden v publikaci Rychtáriková et al., Purplsoc 366-384, 2015.

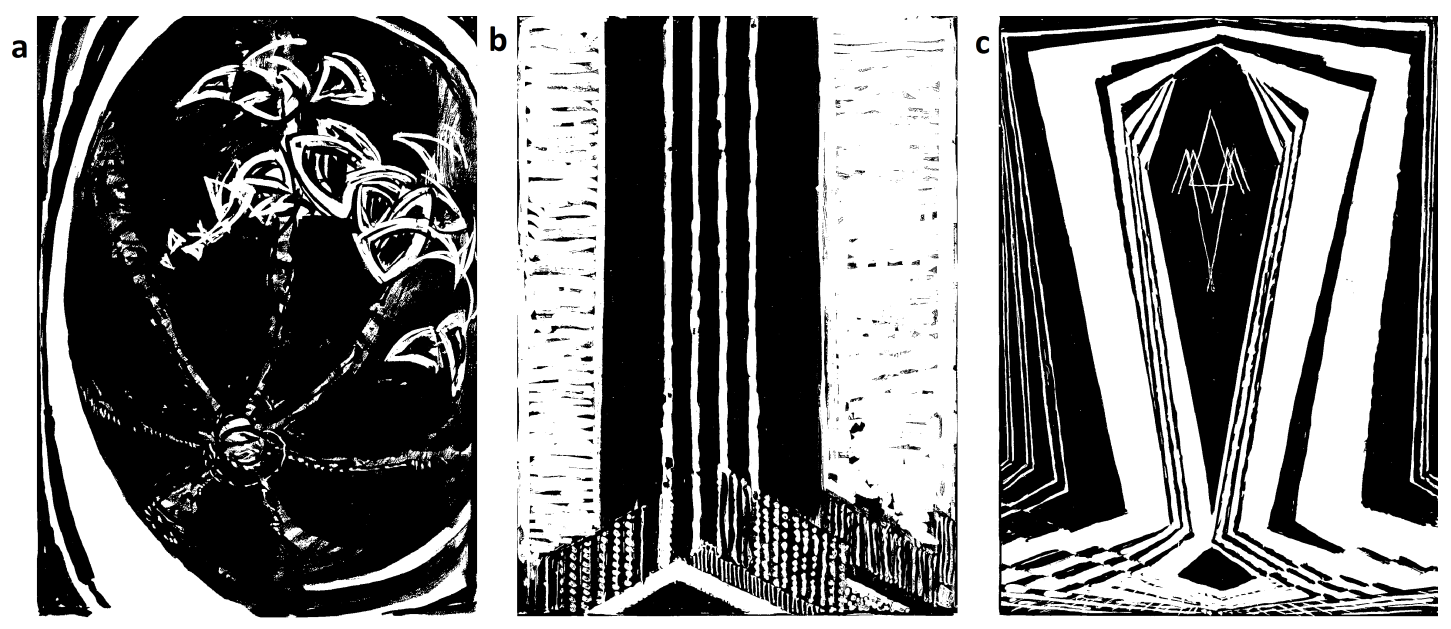

Obr. 1 Príklady Kupkových studii k cykelu Ctyrípríbèby černé a bilé použité v experimentu

V první části experimentu (Obr. 2) měla skupina 86 lidí za úkol roztř́́dit obrázky do pěti skupin podle vizuální podobnosti, a tím určit, jaké rysy jsou pro jejich vnímání obrazu klíčové. Druhá část spočívala v provedení výpočtu entropie obrazu a ve třetí části byly sady výsledků porovnány. Výpočty jsme prováděli pomocí metody, která byla vyvinuta $\mathrm{v}$ Ústavu komplexních systémů a která se nazývá Point Information Gain (PIG). Každý pixel je zde popisován v rámci pravděpodobnosti svého výskytu, respektive výskytu úrovně intenzity v histogramu obrázku. My jsme se rozhodli použít černobílou variantu obrázků, teoreticky je ovšem možné postup aplikovat jak na odstíny šedi, tak barevné odstíny. V našem prípadě šlo tedy skutečně jen o zastoupení bílé a černé barvy $\mathrm{v}$ obraze $\mathrm{v}$ kontextu jejich okolí (tedy o vizuální detekci tvarů). Informační hodnota bodu (Point Information Gain, informační př́nos bodu) založená na pravděpodobnosti jeho výskytu se získá tak, že postupně každý pixel z obrázku odebereme a měříme informační hodnotu celku před a po odebrání - tak získáme informační hodnotu jednoho každého pixelu (jde tedy o kombinaci intenzity bodu (dvě hodnoty, černá a bílá) a pravděpodobnosti jeho výskytu (singulární vs. běžný bod)). Získáme tak Point Information Gain Entropy (PIE), což je suma všech PIG pro daný obrázek. Dále můžeme získat PIED, Point Information Entropy Density, která navíc nepotlačuje vzácné body: nenásobí se zde počtem bodů se stejnou hodnotou PIG (tento výpočet však 
nebyl v experimentu použit). Důležité také je, že pro potřeby naší práce jsme nevyužili Shannonovu, ale Rényiho entropii. Rényi počítá s parametrem $\alpha$ (nedimenzionálním škálovacím exponentem) a výhoda Rényiho entropie tkví především v tom, že ji lze aplikovat na multidimenzionální či multifraktální systémy (v rámci našeho výzkumu jde zjednodušeně řečeno o oblasti obrazů s různou mírou detailnosti). Různé hodnoty parametru $\alpha$ zdůrazňuji různé oblasti souboru dat (zde obrazu) s různou intenzitou. Rényiho entropie, a tedy i PIG, PIE a PIED, jsou aditivní veličiny, tj. hodnoty pravděpodobností výskytů se sčitají. Získáváme tedy hodnotu PIG pro každý bod (pixel) v obraze při určité hodnotě Rényiho koeficientu alfa (která určuje práh viditelnosti $\mathrm{v}$ závislosti na vzácnosti bodů):

$$
P I G_{\alpha, x, y}=\frac{1}{1-\alpha} \log _{2} \frac{\sum_{i=1}^{n} p_{i, x, y}^{\alpha}}{\sum_{i=1}^{n} p_{i}^{\alpha}}
$$

a následně

$$
P I E_{\alpha}=\sum_{j=0}^{m} \sum_{k=0}^{o} P I G_{\alpha, x, y}
$$

Ve výše uvedených rovnicích je $\alpha$ bezrozměrný Rényiho koeficient, $p_{i}$ a $p_{i, x, y}$ představují pravděpodobnosti výskytů pixelů sintenzitou $i \quad \mathrm{v}$ histogramu obrazu a $\mathrm{v}$ histogramu, $\mathrm{z}$ něhož byl odstraněn jeden pixel intenzity $i$ na pozici $(x, y)$ v obraze. Proměnná $i$ v našem př́padě dosahuje hodnot 1 a 2 (tj. černá a bílá). Binární logaritmus udává výslednou informaci v bitech. V rovnici pro výpočet PIE určují veličiny $m$ a $O$ rozlišení digitálního obrazu, tj. počty pixelů $\mathrm{v}$ horizontálním a vertikálním směru obrazu.

PIG a PIE jsme vypočítali dvěma způsoby: z celku obrázku, kdy se vytvářejí statistiky výskytu intenzit z celé plochy obrazu (globální informace) a "z křřže", kdy se počítá jen s informací získanou ze dvou ramen křriže tvořeného pixely na osách $\mathrm{x}$ a y protínajících se $\mathrm{v}$ určeném bodě a získáme lokální informaci. V druhém př́padě zároveň vzniká prostor pro definování okolí, což představuje námět na další výzkum. Celková informace (každého obrázku při dané hodnotě parametru $\alpha$ ) byla nakonec vypočítána jako vektor PIE vypočítané z celku obrázku a z kř́žze (označení Total). Algoritmus pro výpočet PIG a PIE je uvedený v Open Access publikaci Rychtáriková et al. Entropy 18(3). Freeware Image Info Extractor Professional pro výpočet všech uvedených veličin je dostupný přes odkaz uvedený ve článku Entropy 18(3) nebo je v nejnovější verzi dostupný na požádání u autorů.

Získali jsme tak dvě matice neboli pravděpodobnostní distribuce, které byly použity jako vstupní data regresní analýzy (použili jsme regresní analýzu PLSR (Partial Least Squares Regression)): vysvětlující proměnná (predictor matrix) obsahovala vektory hodnot PIE $\alpha$ jako funkci parametru $\alpha$ pro každý obrázek a cílová či vysvětlovaná proměnná (response matrix) znázorňovala vektory klasifikace od tríditelů. Regresní analýza nám umožnila tyto dvě pravděpodobnostní distribuce porovnat, tj. zmapovat topologický prostor s jeho překryvy a významnými body, se záměrem nalézt spektrum hodnot parametru 
$\alpha$, které popisuje, tedy předvídá trí́dění obrázků. Tyto hodnoty, výstupy PLSR, byly popsány jako regresní koeficienty $\beta$. Výsledné pozitivní hodnoty $\beta$ měly prřmý vliv na třídění, zatímco negativní byly $\mathrm{k}$ modelu lidského vnímání danému PLSR v negativním vztahu.
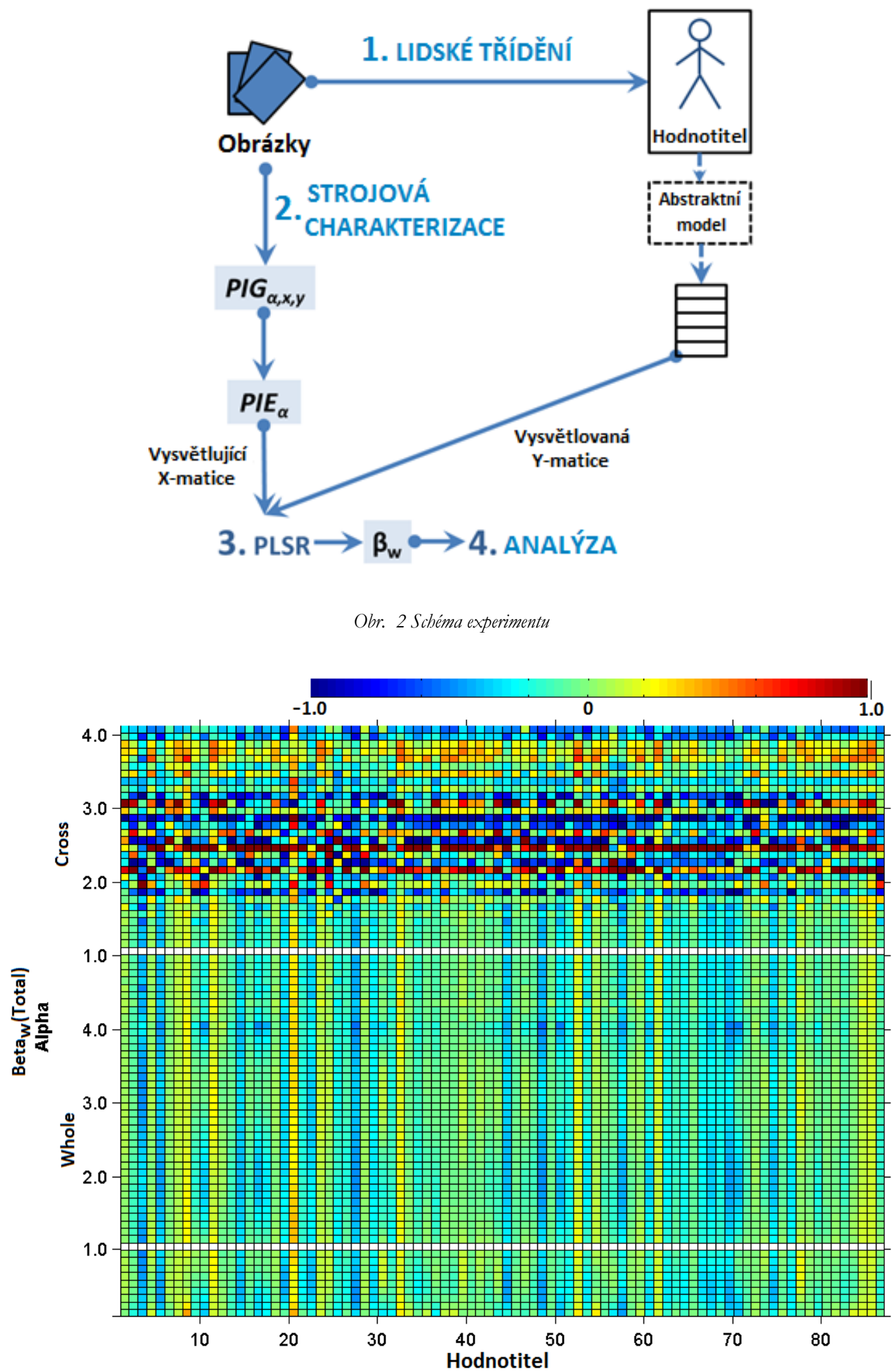

Obr. 3 Výsledky: Váǎ̌ené regresni koeficienty $\beta_{w}$ pro lokálni (Cross) a globálni (Whole) informačni entropii prǒspèvkiu bodů (PIE) odděleně 
Na obrázku vidíme normalizované vážené regresní koeficienty $\beta_{\mathrm{w}}$, které jsme získali pomocí PLSR popisující váhu Rényiho koeficientu pomocí PLSR. Červená barva znamená, že koeficienty mají pozitivní vztah k modelu, modrá barva znamená, že mají negativní vztah k modelu. (Zelená znamená neutrální vztah.)

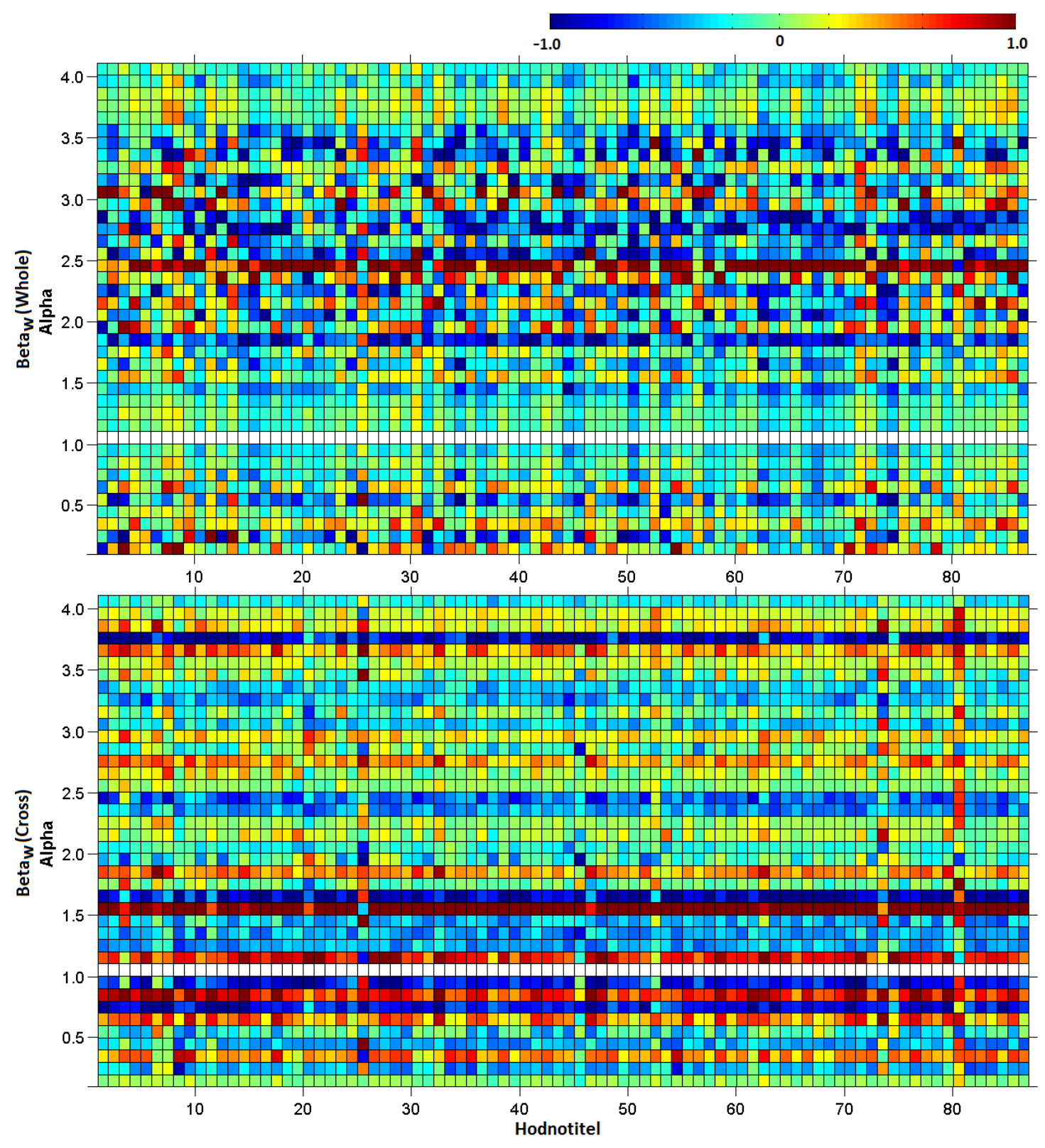

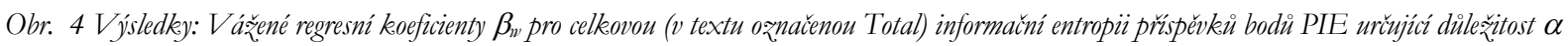
pro trüdéni obrázkù bodnotitely

Rozdíl mezi dvěma grafy (Obr. 3 a 4) je dán tím, že v prvním prrípadě je PLSR pro vektory PIE(Whole) a PIE(Cross) počítána odděleně, $v$ druhém př́padě byla PLSR počítána s vektorem PIE(Total) složeným ze subvektorů PIE(Whole) a PIE(Cross). 
Vážené regresní koeficienty $\beta_{\mathrm{w}}$ vypočítané z hodnot $\mathrm{PIE}_{\alpha} \mathrm{z}$ kř́že, které sloužily jako vstup do PLSR, jsou

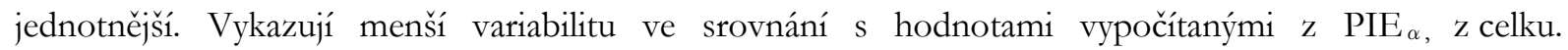
Signifikantní část koeficientů $\beta_{\mathrm{w}}$ se vyskytuje v rozmezí 0,7-1,6. Silnou zónu lokálního minima můžeme vidět na hodnotě $\alpha=3,7$. Většina hodnotitelů mají minimální a maximální hodnoty $\beta_{\mathrm{w}}$ na $\alpha=1,5$ a 1,6 . Hodnoty $\beta_{\mathrm{w}}$ signifikantní pro lidské vnímání se pohybují mezi hodnotami $\alpha 2,4-2,5$ a $2,7-2,8$. Mnoho hodnotitelů klasifikovalo obrázky podle $\alpha=2,1$ (23 hodnotitelů), 2,2 (17 hodnotitelů), 2,5 (10 hodnotitelů) a 3,0 (17 hodnotitelů). Signifikantní zóna koeficientu $\beta_{\mathrm{w}}$ pro lokální informaci je př̀i $\alpha \leq 1,6$ se silnou oblastí v $\alpha \leq 3,0$.

Pro globální informaci vypočítanou pomocí PIE (z celku obrazu) jsou signifikantní hodnoty spektra koeficientů $\beta_{\mathrm{w}}$ jakožto funkce Rényiho koeficientů $\alpha$ situovány mezi 1,8 a 3,4. Většina hodnotitelů (62) měla maximální hodnotu $\beta_{\mathrm{w}}$ mezi 2,3-2,5. Výskyt lokálního minima $\mathrm{v} \alpha$ se rovná 1,$8 ; 2,0 ; 2,2 ; 2,5 ; 2,7 ; 2,8$; 3,1 a 3,3 ve většině př́padů (47 hodnotitelů). Kombinace maximálních hodnot $\beta_{\mathrm{w}}$ koeficientů v $\alpha=2,4$ s minimálními hodnotami $\alpha 2,7$ a 3,3 je nejčastější (11 hodnotitelů pro každý $\alpha$ parametr). U některých hodnotitelů také můžeme pozorovat silnou oblast $\beta_{\mathrm{w}}$ koeficientu v $\alpha \leq 0,5$.

Můžeme zde tedy učinit opatrný závěr, že lidé vnímají především globální informaci (zde celek obrazu) předložených obrázků. Lokální informace (detail) je pro proces klasifikace sekundární. Během klasifikace se lidé ř́dili především většími oblastmi a nesoustředili se tolik na detaily.

V našem výzkumu jsme navrhli a realizovali způsob porovnání lidských a strojových dat, které jsou na sobě nelineárně závislé. Výsledky, jakkoli byl náš experiment spiše pilotním výzkumem, jsou poměrně přesvědčivé - podařilo se nám najít určité úrovně informační entropie (konkrétně parametru $\alpha$ Rényiho entropie), u nichž došlo ke shodě mezi lidmi, kteři rozdělovali obrázky do skupin, a strojovým výpočtem, což je dobrá odrazová pozice pro dalši zkoumání, konkrétně experimentování s okolím bodu a rozlišením oblastí obrazu a nastavováním parametrů Rényiho entropie.

Naše práce byla pokusem na základě rešerše v oblasti analýzy obrazu a strojového vidění a pomocí vlastního softwaru i designu experimentu prozkoumat vztah strojového a lidského vidění: a to nejen v oblasti praktické aplikace, ale částečně i jeho teoretických aspektů anebo spiše zamlčených předpokladů: Do jaké míry může být strojové „viděni““ porovnáno s lidským vnímáním? Nebo je jeho výpočetní charakter s kontinuitou lidské percepce neslučitelný? Je umění oblastí, která může být podrobena matematické analýze, anebo se jí ze své podstaty vzpírá? Je abstraktní umění tím hraničním fenoménem, který je jak historicky, tak technicky oblastí srozumitelnou jak pro prirrozené lidské vnímání, tak pro výpočetní technologie a digitální média? Jsou abstraktní díla využitelná jako př́klad efektivního získávání informace z komplexního prostředí? Je vztah informace a komplexity univerzální v tom smyslu, že je lidské vnímání jeho projevem? Existují univerzální pravidla utváření a percepce vzorů aplikovatelná na morfogenezi, lidské vnímání i strojové učení? To vše jsou otázky, které náš výzkum vyvolává, aniž by si 
činil nároky na jejich úplné zodpovězení. Považujeme nicméně kladení otázek za důležitou součást jakéhokoliv zkoumání.

V době algoritmizovaného strojového vidění, které proniká do všech oblastí lidské činnosti, je více než na místě promýšlet vztah mezi tvorbou a kalkulovaným obrazem a zároveň vztah mezi lidským vnímáním a strojovým viděním: tedy problematiku, která zdaleka není jen doménou vědy, ale je výraznou součástí globální proměny sociálních a politických aspektů současné společnosti a její algoritmicky rrízené budoucnosti. Náš príspěvek do diskuze byl vytvořen se záměrem zpochybnit hegemonii neuronových sítí a poukázat na další možnosti analýzy obrazu, které by mohly dosáhnout podobné efektivity analýzy a poskytnout odlišný úhel pohledu. 


\section{Doporučená literatura}

Malečková, D. Obrą, informace, komplexita. Studium vizuální informace s využitím funkce informační entropie se zaměřením na výtvarnou abstrakci, dizertační práce, obhájena na ÚISK FF UK, 2017. Dostupné online z: file:///Users/ditama/Downloads/IPTX_2010_2_11210_0_289343_0_105398.pdf

Rychtáriková R., Korbel J., Macháček P., Císař P., Urban J., Štys D. Point Information Gain and Multidimensional Data Analysis. Entropy 18(2), 372, 2016.

Rychtáriková R., Malečková D., Urban J., Bárta A., Novotná M., Zhyrova A., Náhlík T., Štys D. Study of Human Perception with the Usage of Information Entropy Analysis of Patterns, in PURPLSOC: Pursuit of Pattern Language for Societal Challenges/PURPLSOC The Workshop 2014 1), Baumgartner and Sickinger (eds.), pp. 366-384, ISBN 978-3-7375-5458-9, epubli GmbH (Verlag), 2015, Rakousko.

Bálek, Martin; Nešetřil, Jaroslav. Towards mathematical aesthetics. Charles Univ., 2004. Dostupné online z: https://iti.mff.cuni.cz/series/2004/231.pdf

L. A. Gatys \& A. S. Ecker \& M. Bethge: A Neural Algorithm of Artistic Style, 2015. Dostupné online z: https://www.researchgate.net/publication/281312423_A_Neural_Algorithm_of_Artistic_Style

Neil Johnson, Guannan Zhao, Eric Hunsader, Hong Qi, Nicholas Johnson, Jing Meng \& Brian Tivnan: Abrupt rise of new machine ecology beyond buman response time, 2013. Dostupné online z: https://www.researchgate.net/publication/256490201_Abrupt_rise_of_new_machine_ecology_beyond_ human_response_time

\section{Poznámka o autorech}

Dita Malečková (1978) vystudovala filozofii a informační vědu na Univerzitě Karlově. Působí na Studiích nových médií FF UK. Zabývá se filozofickými aspekty médií, průniky umění a technologie a současnou vizuální kulturou v kontextu nových médií a technologií. E-mail: ditamorg@gmail.com

Renata Štysová Rychtáriková (1983) vystudovala obor biotechnologie, působí na Ústavu komplexních systémů Jihočeské univerzity. Osou jejího profesionálního zaměření je problematika měření dynamických systémů. E-mail: rrychtarikova@frov.jcu.cz

Jan Urban (1978) je vedoucím Laboratoře zpracování signálu a obrazu Fakulty rybářství a ochrany vod Jihočeské univerzity. Zabývá se zpracováním a analýzou diskretizovaného signálu a obrazu, především z biologických měření. E-mail: urbanj@frov.jcu.cz 